Peer-Reviewed Article
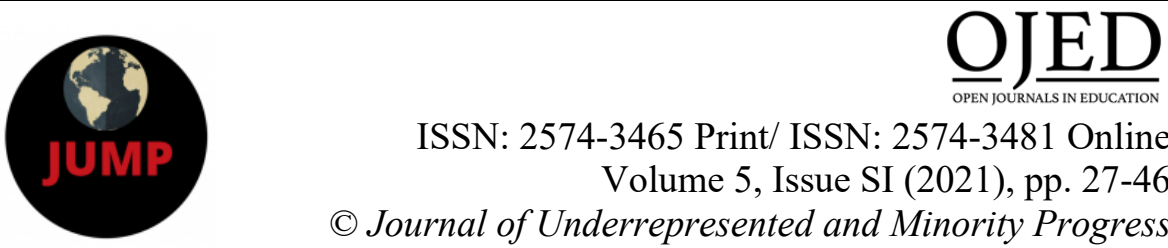

ISSN: 2574-3465 Print/ ISSN: 2574-3481 Online

Volume 5, Issue SI (2021), pp. 27-46

(C) Journal of Underrepresented and Minority Progress

http://ojed.org/jump

\title{
COVID-19 Crisis Management at Historically Black Colleges and Universities (HBCUs): A Contemporary Approach to Governance and Leadership
}

\author{
Melanie S. Johnson \\ Southern University and A\& M College/USA \\ Samantha A. Thompson \\ Southern University Law Center/USA
}

\section{ABSTRACT}

COVID-19 has forever changed the trajectory of higher education institutions and the delivery of their services, particularly at Historically Black Colleges and Universities (HBCUs). This unprecedented pandemic necessitated $H B C U$ s to undergo rapid, significant alterations to their academic, instructional, and technological infrastructures in order to remain operational and to continually provide students with academic support services and a conducive environment for higher learning. Therefore, how $H B C U s$ approach the strategic transformation of their campus operations with limited resources in order to remain competitive is vital to their organizational continuity. Considering these challenges, this study examined the role of crisis management as well as investigated the efficacy of decisionmaking processes of the governing boards and leadership at four (4) HBCUs.

Keywords: COVID-19, crisis management, decision-making, governance and leadership, Historically Black Colleges and Universities (HBCUs). 


\section{INTRODUCTION}

The higher education landscape in the United States has been changed forever by the COVID-19 pandemic, which has disproportionally and adversely affected segments of the underrepresented population; Black, Hispanic, and American Indian or Alaska Native people (Center for Disease Control and Prevention, 2020). According to the Center for Disease Control and Prevention (CDC), these disproportionate effects are clearly demonstrated in the public health data, which highlights Black Americans are 4.7 times more likely to be hospitalized, and 2.1 times more likely to die from COVID-19 (Coronavirus) than their White counterparts (Center for Disease Control and Prevention, 2020). These stark statistics engender additional challenges for Historically Black Colleges and Universities (HBCUs) and necessitate effective governance and leadership to address the transformational implementation of new academic, public health, and technological measures to adequately serve their majority Black student populations. The authors believe that the success, operability, and effectiveness of HBCUs are inextricably linked to educational outcomes for many underrepresented minority groups. Consequently, as HBCUs attempt to navigate the vicissitudes of this public health pandemic, the strategies and practices of crisis management should be integrated within decision-making processes at these institutions.

\section{COVID-19 and Higher Education}

The COVID-19 pandemic propagated a novel, unpredictable, unprecedented, and time-sensitive public health crisis, for which most higher education institutions, including HBCUs, were vastly unprepared. Publicstate funded HBCUs have historically and contemporaneously faced endemic problems as higher education institutions with their collective inadequate funding history, distinct missions, and unique student population demographics (Thurgood Marshall College Fund, 2019a). According to the Thurgood Marshall College Fund (2019b), HBCUs disproportionately enroll "low-income, first-generation and academically underprepared college students" (p.1), which comprise a significantly underrepresented demographic at non-HBCUs across the country (Richards \& Awokoya, 2012). These issues, coupled with the COVID-19 crisis, have placed HBCUs at a crossroad, where their success and sustainability to remain open hinges on effective governance and executive leadership (Nelms \& Schexnider, 2020). Furthermore, as a result of the Coronavirus pandemic, HBCU leaders across the country are advocating for additional federal financial support. These funds are needed to defray the augmented operational costs associated 
with addressing this public health crisis, which could have detrimental effects on the institutions' viability (Valbrun, 2020).

\section{Purpose of the Study}

In this study we examined whether governing boards and leadership at public state-funded Historically Black Colleges and Universities (HBCUs) were effective in their decision-making in the midst of COVID-19. It is important to contextualize the distinction between governance and leadership in the realm of higher education. Although there is no single or generally accepted definition of governance, one commonly given definition is: the way issues affecting the entire institution, or one or more components thereof, are decided (Kezar et al., 2006). In addition, governance has been described as structures, legal relationships, authority patterns, rights and responsibilities, and decision-making patterns (Kezar, 2014). Leadership, on the other hand, is defined as the action of leading a group of people or an organization, which in higher education represents upper administration on the institutional level (Astin \& Astin, 2000). Therefore, leadership, especially the ways in which leaders are chosen, the expectations that are placed on them, and how they manifest their authority, can provide extraordinary insights about the implementation of policies at these institutions (Alexander et al., 2020). Considering these challenges, this study seeks to investigate the role of crisis management within the governance and leadership framework of HBCUs and its impact on the efficacy of decision-making processes at these institutions.

\section{LITERATURE REVIEW}

\section{Background on Historically Black Colleges and Universities}

Historically Black Colleges and Universities were founded mostly in the early $19^{\text {th }}$ century, with the clear mission to provide a quality education for Black Americans at a time when they were not allowed to embark on their educational pursuits at a predominantly White institution (PWI) (Thurgood Marshall College Fund, 2019). Section 322(2) of the Higher Education Act of 1965, as amended (HEA), defines HBCUs as:

"any historically black college or university that was established prior to 1964 , whose principal mission was, and is, the education of Black Americans, and that is accredited by a nationally recognized accrediting agency or association determined by the Secretary [of Education] to be a reliable authority as to the quality of training offered or is, according to such an agency or association, making reasonable progress toward accreditation." (U.S. Department of Education, 2020, p.1) 
According to the U.S. Department of Education, there are currently 101 HBCUs in the nation, with 50 private institutions and 51 public state funded colleges and universities, $89 \%$ of which are primarily located within the south/south eastern part of the United States (National Center for Education Statistics, 2020). These institutions educate and prepare over 228,000 students each year to be future leaders and scholars in their respective fields (U.S. Department of Education, 2020).

Richards and Awokoya (2012) posit that most HBCUs already face uphill battles with a collective perception of being low performing institutions who tend to lag behind their non-HBCU counterparts in a plethora of critical areas, including graduation and retention rates, as well as financial challenges. In addition to the aforementioned, HBCUs also face woes related to accreditation issues, while having to contend with and constantly quell questions about their relevance and sustainability in contemporary society. With factors such as institutional performance and effectiveness currently pinnacling the priority list in higher education, HBCUs' governance and leadership practices have been under significantly more scrutiny in recent times (Commodore \& Owens, 2018).

\section{HBCUs Governing Structures, Governance and Leadership}

HBCUs have always had a unique mission and played a pivotal role in educating Black Americans. Along with this mission, whether public or private, HBCUs have had to meet this challenge while being grossly underfunded dating back to their founding (Nelms \& Schexnider, 2020). Given that governance structures play a pivotal role in how colleges and universities are funded, and are unique from state to state, it is important to understand the governing structures of public, state funded HBCUs. A study conducted by Freeman, Hilton and Lee (2015) provides an excellent framework explaining the state-supported governing structure of HBCUs across the country. Overall, there are three (3) separate governance structures: 1) statewide; 2) local; and 3) shared. The Statewide Governance structure is comprised of a single, state-level board, typically by a Board of Regents that is responsible for governing multiple institutions. Statewide governing boards have the power to hire presidents and chancellors; set policies and procedures governing all institutions; approve the development of new degrees and programs; set financial priorities for each campus and provide coordination for the entire system of colleges and universities (Freeman et al., 2015). Statewide governing board members are frequently appointed by the Governor and confirmed by the Senate or some legislative body. This statewide governing structure exists at 26 HBCUs across ten states. Southern 
University and A\&M College is the only system-level board in the world that governs multiple HBCUs (Freeman et al., 2015).

The Local Governing Structure is comprised of a single institutional board that provides oversight of all aspects of the institution. They are responsible for the hiring of the president, setting policies and procedures, ensuring financial fidelity, and have the authority to create new programs and degrees. The Shared Governance Structure is comprised of a bicameral statewide and local board. Twenty five percent of HBCUs follow this structure and institutions in this category have an institutionally based governing board that have the responsibilities to choose the president and ensure financial fidelity (Freeman et al., 2015).

Currently, due to COVID-19, HBCUs lacking financial resources have been forced to recognize the need for effective governance and leadership in order to make good decisions regarding how they will move forward and adjust to the new normal to sustain themselves and remain competitive. Recently, HBCU Presidents and leaders met to discuss the future of HBCUs post-COVID-19 and concluded that they must rebrand themselves and consider reimagining their financial and business models after the pandemic (Blanco, 2020). Additionally, current literature suggests that COVID-19 has totally disrupted the traditional mode of instruction at HBCUs, which has created untenable situations that will require effective governance and leadership (Nelms \& Schexnider, 2020). This study will provide insight and approaches to strengthen and improve HBCU governance and leadership through crisis management.

\section{Crisis Management Models}

"Normality is our natural nest, stability our beloved home and certainty our paramount aspiration" (Topper \& Lagadec, 2013, p.1). Unfortunately, uninterrupted normalcy is a figment of the imagination; a fallacy that all too often emerges, engulfs, and eviscerates the stability that organizations thrive on. Traditionally, organizations were cognizant of the crises that need to be addressed, such as natural disasters and egregious organizational misconduct, however, over the past decade the number of incidents related to workplace violence and domestics terror attacks have significantly increased (Lerbinger, 2012), and most recently with COVID-19, a new global pandemic has been added to the fray. While there is no singular approach, model, or theory for crisis management, the body of research concurs that crises typically have the following characteristics: significant, high impact, ambiguous, urgent, and involve high stakes (Coombs, 2015; Heath 2010; Simola, 2014). 
According to Otto Lerbinger, as crises increase in number, visibility and calamity, organizations must accept the reality that crisis management must be factored into their decision-making processes (Lerbinger, 2012). This requires leaders at HBCUs to augment their existing practices with tenets of a model that will help them effectively respond to new challenges. One of the earlier definitions of what constitutes a crisis was provided by Pearson and Clair (1998): "An organizational crisis is a low probability, high impact event that threatens the viability of the organization and is characterized by ambiguity of cause, effects and means of resolution, as well as by a belief that decisions must be made swiftly" (p. 60). Lerbinger (2012) emphasized contemporary society has endured several biological crises in the form of highly communicable and deadly viruses, including SARS, H1N1, Ebola. The emergence of COVID-19 is a prime example of how the field of crisis management, along with its theories and models must be quick to evolve as new crises continually emerge.

Over 34 years ago, the practices that encompass contemporary crisis management models began to take form and structure with the seminal work of Fink (1986). This scholar promulgated a four-stage crisis model comprising the prodromal, acute, chronic, and resolution stages (Fink, 1986). Building upon Fink's work, several other theorists emerged who have propagated conceptual frameworks in the field of crisis management. Gonzalez-Herrero and Pratt's (1996) model suggested the stages of birth, growth, maturity, and decline, and focused on the aspects of issues management, planning-prevention, crisis, and post-crisis management. In 2007, Tony Jaques proposed a new Issue and Crisis Management Relational model that is both distinctive in its nature and structure. While previous models viewed crisis management as a linear and quite sequential process, Jaques' model prioritizes fluidity of decision making among the four elements of Crisis Preparedness, Crisis Prevention, Crisis Event Management, and Post-Crisis Management (Jaques, 2007). The researchers will be using the Issue and Crisis Management Relational Model for this study.

\section{Issue and Crisis Management Relational Model}

Within the Issue and Crisis Management Relational Model, crisis management is viewed as a continuous discipline based on clusters that are both integrative and non-linear (Jaques, 2007). Jaques' (2007) Relational Model addresses both trigger events and underlying causes of crises as well as a focus on the importance of crisis communication. This model is predicated on a "holistic view of crisis management" and underscores the importance of post-crisis activities for preparing to manage future crises 
(Jaques, 2007, p.6). In this model, each element is accompanied by clusters of activities and processes, some of which may overlap and occur simultaneously (Jaques, 2007). Figure 1 illustrates the Issue and Crisis Management Relational Model with its four main elements and related activities.

\section{Figure 1}

Issue and Crisis Management Relational Model

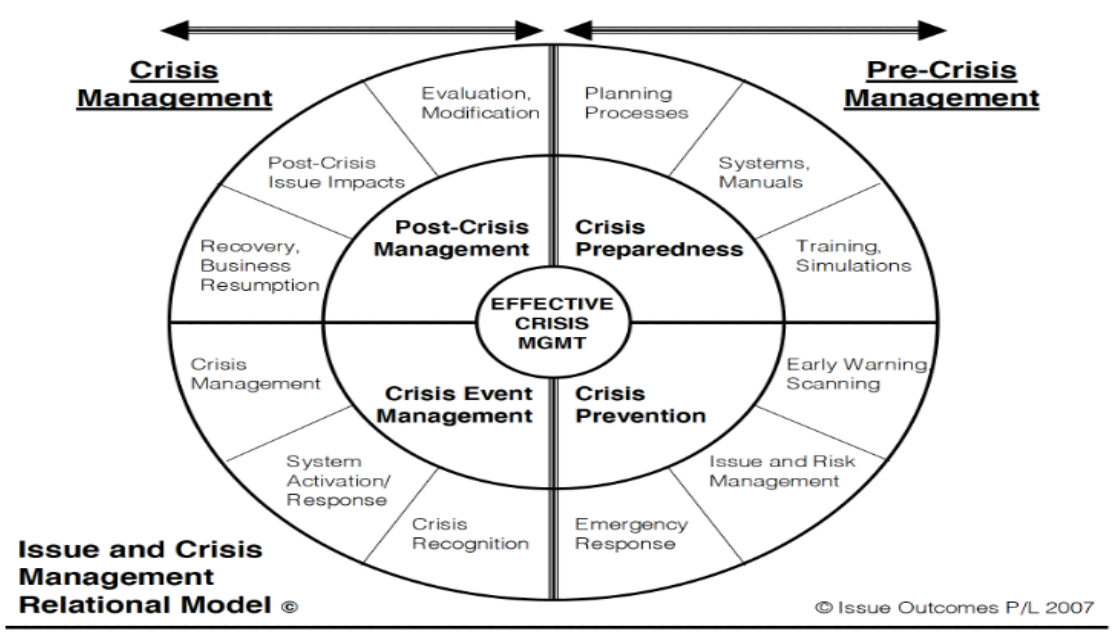

Source:(Jaques, 2007, p.6)

In the Relational Model, two main elements occur in the Pre-Crisis Management phase: 1) Crisis Preparedness and 2) Crisis Prevention. Crisis Preparedness consists of the following practices: Planning Process, Systems Manuals, and Training, Simulations. Whereas Crisis Prevention involves Early Warning Scanning, Issue and Risk Management, and Emergency Response activities. Jaques (2007) elucidates the interconnection and overlap that can occur among cluster activities, for example, Early Warning and Crisis Recognition. The Crisis Management phase entails Crisis Event Management and Post-Crisis Management. Crisis Event management consists of Crisis Recognition, System Activation/Response, and Crisis Management. Post Crisis Management involves Evaluation and Modification, Post Crisis Issue Impacts, and Recovery, Business Resumption. Table 1 provides the definitions of each activity. 
Table 1

Issue and Crisis Management Relational Model Description

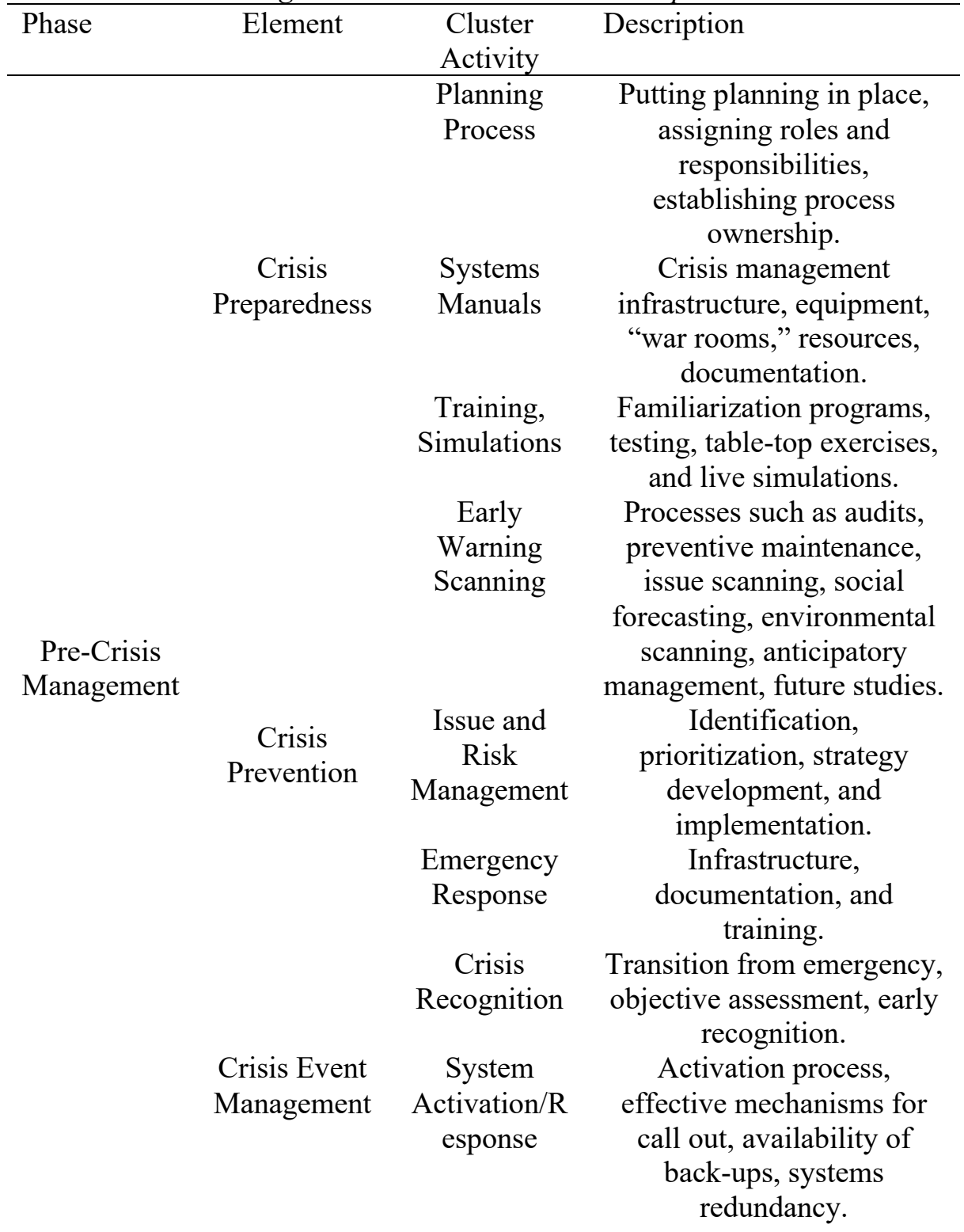




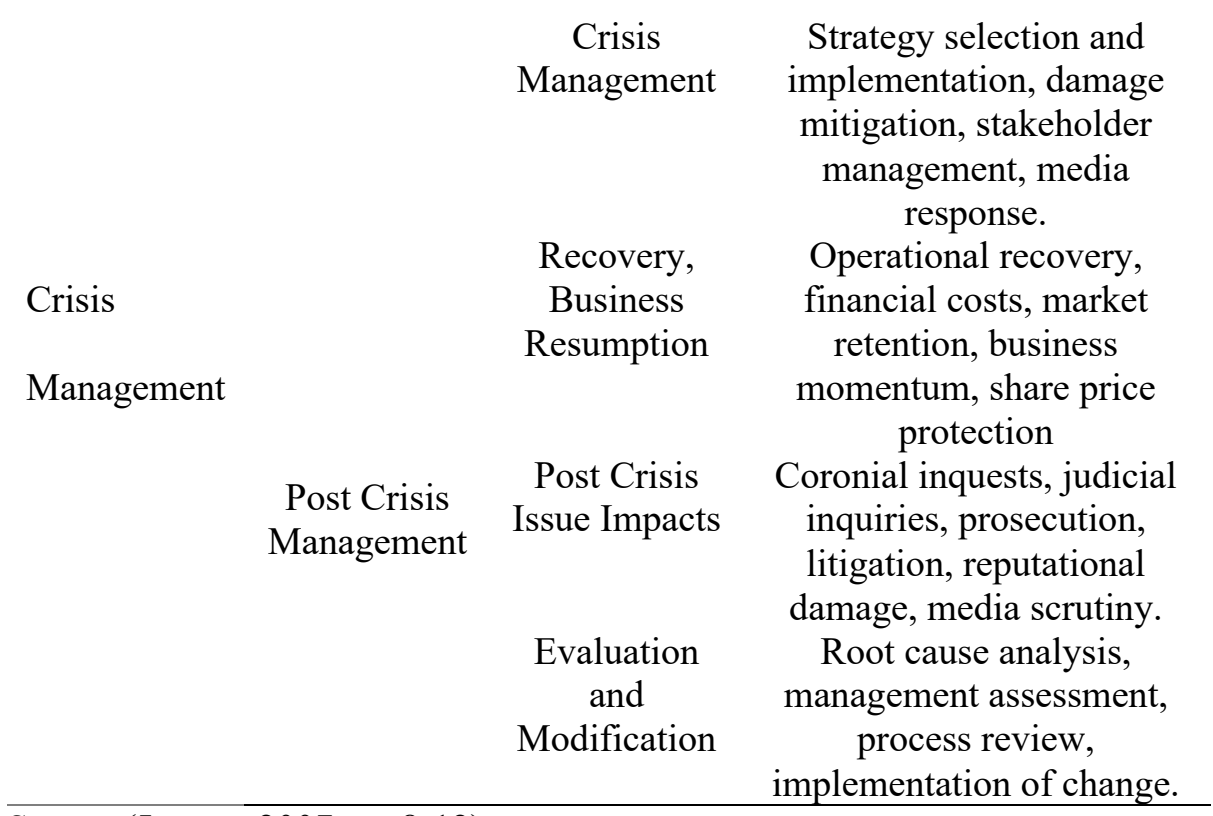

Source:(Jaques, 2007, pp.8-12)

In his description of the cluster activities, Jaques (2007) underscores the importance of the level of action, engagement, and commitment from senior leadership in both the Pre-crisis management and Crisis Management phases. Crisis Management activities should not occur in silos, and leadership ought to prioritize the crisis communication mechanisms, selection of team members, and necessary resources to achieve crisis management goals (Jaques, 2007).

\section{Board Responsibility for Crisis Management}

In addition to the Relational Model, Jaques (2017a) also promulgates the important notion that board members have a unique responsibility to engage in crisis management best practices to mitigate severe risks to their organizations. Essentially, poor crisis management can have egregious effects on organizational reputation and financial performance (Jaques, 2017b). In the current climate, stakeholders have high expectations related to board member decision making and demand higher levels of transparency and accountability from university leadership (Jaques, 2012; Jaques, 2017a;). Consequently, university board members and senior leadership must partake in Crisis Proofing to address the aforementioned concerns. Crisis Proofing is an emergent concept that eschews the practice of responding to crises when 
they occur and posits that board members must work to prevent crises from happening in the first place (Jaques, 2017b). As HBCUs navigate the process of addressing the modern calamities associated with COVID-19, board members, and senior leadership must develop the requisite crisis leadership and crisis management capacities that will engender true organizational impact.

\section{RESEARCH METHOD}

Qualitative content analysis was used as the method of inquiry for this study. The significance of this study lies in its attention to an examination of an underrepresented area of research in higher education. Content analysis is described as the systematic reading of a body of texts, images, and symbolic matter, not necessarily from an author's or user's perspective (Krippendorff, 2013). For the purpose of this study, content analysis entails the subjective interpretation of the content of data through the methodical categorization process of coding and identifying themes or patterns (Yanovitzky \& Weber, 2020; Hsieh \& Shannon, 2005). The authors chose content analysis because it offers an adaptable and pragmatic method for examining decision making practices related to crisis management at HBCUs. The classic steps for content analysis were followed for this study, including formulating the research question, selecting the sample to be analyzed, defining categories, determining the coding process, and analyzing results (Hsieh \& Shannon, 2005).

\section{Research Question}

The research question formulated for this study is: How effective were the decision-making processes within governance and leadership frameworks at public state-funded HBCUs in the wake of COVID-19?

\section{Sample}

The researchers purposely sampled a total of four (4) public state funded HBCUs located in the southern part of the United States to assess the efficacy of their crisis management decision making in the wake of COVID19. These universities were chosen because of their unique Board governing structures. Within the state of Georgia, two (2) HBCUs were selected: Fort Valley State University and Savannah State University. Two additional universities, Grambling State University and Southern University and A \& M College located in Louisiana were utilized for this study. Using the primary research question as a guide, seventy-five (75) documents relevant to university decision-making were reviewed, including university board 
minutes, university press releases, strategic plans, hazard mitigations plans, videos, and emergency response website data.

\section{Categories}

The documents were analyzed based on the key variables of Jaques (2007) Issue and Relational Crisis Management model areas of Crisis Preparedness, Crisis Prevention, Crisis Event Management, and Post-Crisis Management and coded for concepts and occurrences related to essential cluster activities (See Appendix).

\section{Coding Process}

To code the data, the researchers used a Computer Assisted Qualitative Data Analysis Software (CAQDAS), ATLAS.ti. ATLAS.ti can search, code as well as relate data from text, audio, video, and images (Thompson, 2018) and has the capability to coalesce data into cases and create memos and codes that are grouped thematically (Bassett, 2010). This study implemented the deductive approach and used a priori coding. The coding categories were established prior to the analysis based on Jaques (2007) Issue and Relational Crisis Management model cluster activities (see Appendix). For this study, the researchers opted to code for the frequency of these key terms.

\section{Analysis of Results}

The researchers used Atlas.ti to produce a word cloud of emergent themes, co-occurrence theme table (see appendix) to analyze themes that emerged from the study. The findings presented were obtained by coding and analyzing data from four (4) HBCU campuses, which consist of different and unique leadership and governing board structures from state to state in order to answer the research question of this study.

\section{Fort Valley State University Background}

Fort Valley State University is an 1890 land grant institution located on 1,365 acres in Fort Valley, Georgia and was founded as the Fort Valley High and Industrial School (FVHIS) in 1895 by eighteen men, at least half of whom were former slaves (Fort Valley State University, 2020). Fort Valley State achieved university status in 1996, and from 2014-2016 was recognized as one of the top producers of African American students in math related undergraduate degrees. Fort Valley State University is a part of the University System of Georgia, consisting of thirty-five public colleges and universities located in every key region of the state (Fort Valley State Faculty Handbook, 
2020). Within this system, Fort Valley is recognized as a senior state university. The university's leadership consists of a President, Provost \& Vice President of Academic Affairs; Chief of Staff; Vice President of Student Affairs and Enrollment Management, Vice President of Business and Finance, Vice President of University Advancement, and Vice President of Economic Development and Land grant Affairs (Fort Valley State University, 2020). It is considered to be part of a statewide governing structure, with a consolidated superboard comprised of 35 colleges and universities in the State of Georgia (Fort Valley State University, 2020).

\section{Savannah State University Background}

Savannah State University is located in Savannah, Georgia and was founded in 1891 as a result of the 1890 Second Morrill Land Grant Act (Savannah State University, 2020). Today, Savannah State University has over 3,600 graduate and undergraduate students, 174 full time faculty members and offers associates, bachelors, and master's degrees in the fields of Business, Arts, Sciences and Education (National Center for Education Statistics, 2020). Savannah State University is also part of the University System of Georgia, a statewide consolidated superboard consisting of thirtyfive public colleges and universities located in every key region of the state (Savannah State University Faculty Handbook, 2020). The Savannah State University leadership consists of a University President, Interim Provost/Vice President for Academic Affairs, Interim Vice President for Business \& Financial Affairs, Vice President for Enrollment Management, Vice President for University Advancement, Dean of Students, Assistant Vice President for Student Affairs, and Vice President for Marketing and Communications (Savannah State University, 2020).

\section{Grambling State University Background}

Grambling State University opened on November 1, 1901 in Grambling, Louisiana, as the Colored Industrial and Agricultural School. Grambling State University is a part of the University of Louisiana System Board of Supervisors consisting of nine (9) public colleges and universities located in every key region of the state (University of Louisiana System, 2020). The University of Louisiana System is one of the largest higher education systems in the country consisting of a public, multi-campus university system dedicated to the service of Louisiana and its people. The system includes Grambling State University, Louisiana Tech University, McNeese State University, Nicholls State University, Northwestern State University, Southeastern Louisiana University, University of Louisiana at 
Lafayette, University of Louisiana at Monroe, and University of New Orleans. The Grambling State University leadership consists of a President, Provost and Vice President of Academic Affairs, Vice President/Athletic Director, Vice President of Institutional Advancement, Research and Economic Development, and an Executive Vice President and Chief Operating Officer (University of Louisiana System, 2020). Grambling State University is part of a consolidated statewide governing board, which makes it one of the most unique systems in the country.

\section{Southern University \& A \& M College Background}

Southern University and A \& M College is located on a 512-acre campus in Baton Rouge, Louisiana and was originally chartered in January 1880 by the General Assembly of the State of Louisiana based on a bill sponsored in 1879 by three key individuals: Pickney B. S. Pinchback, T. T. Allain, and Henry Demas (Southern University Office of Institutional Effectiveness, 2020, p.1). Southern University and A\&M College System is the only Historically Black College and University (HBCU) system in the world with locations in Baton Rouge, New Orleans, and Shreveport (Louisiana Board of Regents, 2020). Southern University and A\&M College's leadership consist of a President/Chancellor, Executive Vice President, Vice Chancellor for Finance and Administration, Vice Chancellor for Student Affairs \& Enrollment Management, Vice Chancellor for Student Success and Vice Chancellor for Research and Strategic Initiatives. The Southern University System is a statewide governing structure, comprised of four separate institutions within a coordinating system.

\section{RESULTS}

This study examines whether the utilization of a crisis management model impacts the effectiveness of the decision-making processes within governing boards and leadership at public-state funded HBCUs in the wake of COVID-19.

\section{Crisis Preparedness}

In the area of Crisis Preparedness, HBCUs had to make many decisions in a short period of time, which required the following: developing a COVID-19 task force, assigning duties and responsibilities within their institutions, conducting meetings, and planning of campus operation. These activities required decision-making and approval from university leaders and university board members. The most salient theme that emerged was planning campus operations to ensure the health and safety of everyone on campus. Secondly, to effectively mitigate problems during COVID-19, all HBCU 
institutional leaders spent a large amount of time and effort assigning roles and responsibilities to qualified personnel to prepare and manage classroom infrastructural changes, so students, faculty and staff could return to their respective campuses after the national lockdown was over (University System of Georgia, 2020; University of Louisiana System, 2020; Southern University System, 2020). In addition, university leaders and governing boards were tasked with the responsibility of financially supporting the purchase of necessary technology and equipment to transition from face-to-face to remote or hybrid learning in the midst of COVID-19. Additional findings also suggest that how HBCUs responded to the COVID-19 crisis was of critical importance. With respect to emergency response to COVID-19, findings indicated that fifty percent of the HBCUs were quick to begin operating online classes and providing remote campus operations to attempt to recover from the unprecedented pandemic, while the other fifty percent lagged behind for financial reasons (University System of Georgia, 2020; University of Louisiana System, 2020; Southern University System, 2020). In addition, the data showed that online training simulations were facilitated for faculty and fifty percent of the HBCUs mandated Quality Matters training for faculty to ensure quality online teaching to maintain academic excellence at their institutions. These findings indicate that overall, the leadership and governing boards were effective in their decision making in the area of Crisis Preparedness.

\section{Crisis Prevention}

In the area of Crisis Prevention, findings indicated that half of the HBCUs studied had a crisis management plan in place before COVID-19, while the other fifty percent did not (University System of Georgia, 2020; University of Louisiana System, 2020; Southern University System, 2020). Findings also indicated that the HBCUs university leaders from all institutions developed partnerships with health care providers for emergency response purposes to address and implement COVID-19 testing protocols and telehealth procedures for faculty, staff, and students to return to their respective campuses. In the area of risk management, all of the HBCUs campuses had problems with the purchasing of proper PPE due to logistical and financial constraints, as well as challenges with the required personnel for the cleaning and sanitization of the buildings (University System of Georgia, 2020; University of Louisiana System, 2020; Southern University System, 2020). One major finding in the area of Crisis Prevention was that only one (1) university prior to COVID-19 had an Emergency Management Office (EMO) to manage and recover from any type of emergency or disaster and was ready 
to keep faculty staff and students informed on the latest development related to COVID-19 (Fort Valley State University, 2020). This discovery suggests that university leaders at this HBCU had vision as it relates to crisis management. Additionally, findings showed that fifty percent of the HBCU campuses had to prioritize preparing classroom infrastructures on campus to accommodate a hybrid learning environment for students returning to campus in the Spring 2020 semester. (University of Louisiana System, 2020; Southern University System, 2020). Findings also indicated that HBCUs had academic issues related to accommodating students without access to a computer or internet service and effective ways to transition personnel back on their campuses. To further mitigate the crisis and the spread of COVID, all of the board meetings across HBCUs were telephonic or virtual board meetings. These findings show that although HBCU governance and leadership made good decisions, the utilization of a crisis management model would improve their efforts and decision-making process in the area of Crisis Prevention.

\section{Crisis Event Management}

The crisis event management analysis showed that one hundred percent of the HBCUs university leaders, with board approval were mandated to develop COVID-19 task force committees to address and implement COVID-19 testing protocols for faculty, staff, and students focused on supporting its institutions continuing to return to safe in-person instruction. All these decisions were directed by the university institutional leaders and then approved by their respective governing boards (University System of Georgia, 2020; University of Louisiana System, 2020; Southern University System, 2020). With respect to emergency response and mitigation practices, seventy-five percent of the HBCUs were quick to begin offering face to face, hybrid, and/or virtual on-line classes, while providing remote and on-campus operations (University System of Georgia, 2020; University of Louisiana System, 2020). Findings also indicated that one hundred percent of the HBCUs in this study were concerned about accreditation requirements due to COVID-19.

Since COVID-19 shifted most of the courses to online, many HBCUs are now forced to find other ways to assess student learning to meet accreditation requirements (Wood, 2020). One other important finding was that half of the HBCUs handled their COVID-19 mitigation practices differently. These institutions continued to use the age of sixty-five as its measure of people at risk for evaluating requests for alternate remote work arrangements, although the CDC no longer considered a minimum age for those at risk (University System of Georgia, 2020). These findings indicate 
that university leaders and governing board members were effective in their decision-making in the area of crisis event management; and able to do what was in the best interest of their institutions and carry out their fiduciary duties and responsibilities to protect the interests of shareholders, which represents effective good governance (Association of Governing Boards, 2020).

\section{Post-Crisis Management}

Post-crisis management involves root cause analysis, management assessment, process review, and implementation of change (Jaques, 2007). Amid COVID-19, HBCUs have been forced to embrace and implement change quickly. Findings in this study indicate that budget and finance issues during COVID-19 were the most prominent problems HBCUs faced. Due to COVID-19, many HBCUs are confronting possible closures due the potential inability to financially recover from this crisis (Wood, 2020). Moreover, finance forecasting related to opening and closing of campuses, instructional teaching method offerings, and other operational matters decisions were made by the university leaders, appointed task force members and governing board members (University System of Georgia, 2020; University of Louisiana System, 2020; Southern University System, 2020).

Findings also show that assessments and feedback from task force members for evaluations and modification of campus operations were continuous; due to their decisions and recommendations to university leaders and governing board members during COVID-19, HBCUs have been able to sustain themselves and remain open. For example, one HBCU's administration implemented a phased plan to bring faculty and staff back to campus and appointed a COVID-19 preparedness \& response team to implement damage mitigation procedures for future crises on campus (University System of Georgia, 2020). These findings suggest that HBCU leadership and governance have not been optimally effective in their decisionmaking related to implementation of change and Post-Crisis Management.

\section{DISCUSSION AND CONCLUSIONS}

In conclusion, "new federal mandates, state performance-based funding formulas, global competition, and budget constraints" (Johnson, 2019, p.23) as well as the presence of COVID-19 have placed multifaceted demands on HBCUs. The tenor, nature, and structure of COVID-19 related changes to HBCU operations were placed in the hands of HBCU senior leadership and governing boards, who, like in most of the country, were themselves grappling with the onslaught of new public health mandates resulting from the pandemic. Due to the lack of resources, and the inability to 
recruit and maintain strong leadership, many HBCUs have been slow to adapt to change (Commodore \& Owens, 2018). Overall, the findings in the study suggest that $\mathrm{HBCU}$ leadership and governance have made effective decisions in the areas of Crisis Preparedness, Crisis Prevention. However, in the areas of Crisis Event Management, and Post-Crisis management, HBCU leadership and governing board members' decision-making related to evaluating requests for alternate remote work arrangements and implementing change were not optimal.

\section{IMPLICATIONS}

Overall, amid COVID-19 it is evident that the use of a crisis management model can successfully improve the effectiveness of the decision-making processes within governance and leadership at public state funded HBCUs. The findings of this study delineate the need for HBCU leadership to incorporate the strategies and activities from an effective crisis management model (Jaques, 2007) to adequately develop their ability to create and implement policies when serious calamities or challenges occur. The change in status quo that will be required for HBCUs to achieve the aforementioned goal is easier said than done. However, the future of underrepresented minority students at these institutions is heavily dependent on strong, committed, and comprehensive leaders who are willing to utilize the gamut of resources at their disposal. As a corollary, HBCUs have proven to be resilient and the authors believe that with the right approach governing boards and leadership at these great institutions can accomplish these herculean tasks.

\section{REFERENCES}

Alexander, A., DeSmet, A., \& Weiss, L. (2020, March 24). Decision making in uncertain times. https://www.mckinsey.com/businessfunctions/organization/our-insights/decision-making-in-uncertain-times\#

Association of Governing Boards of Universities and Colleges. (2020, November 2). Fiduciary duties for institutional board members. AGB. https://agb.org/faqs/faqs-fiduciary-duties-for-institutional-boardmembers/

Astin, A. W., \& Astin, H. S. (2000). Leadership reconsidered: engaging higher education in social change. Higher Education. 133. https://digitalcommons.unomaha.edu/slcehighered/133

Blanco, L. (2020, May 14). HBCU Presidents and leaders discuss the future of colleges and universities post-COVID-19. Black Enterprise. https://www.blackenterprise.com/hbcu-presidents-and-leaders-discuss-thefuture-of-colleges-and-universities-post-covid-19/

Center for Disease Control and Prevention. (2020, November 30). Coronavirus disease 2019 (covid-19): hospitalization and deaths by race/ethnicity. 
https://www.cdc.gov/coronavirus/2019-ncov/covid-data/investigationsdiscovery/hospitalization-death-by-race-ethnicity.html\#footnote02

Coombs, W. T. (2015). The value of communication during a crisis: Insights from strategic communication research. Business Horizons, 58(2), 141-148. https://doi.org/10.1016/j.bushor.2014.10.003

Commodore, F., \& Owens, L. (2018, November 4). Governing HBCUs for the Future. Diverse Issues in Higher Education, 1-

2. https://diverseeducation.com/article/131084/

Fink, S. (1986). Crisis Management: Planning for the Inevitable. American Management Association.

Freeman, S., Hilton, A.A. \& Lee, J.M. (2015). Governing Boards at HBCUs. ASHE/Denver.http://works.bepress.com/sydney freeman $\mathrm{jr} / 40 /$

Fort Valley State University (2020a). Faculty Handbook. https://www.fvsu.edu/wp-content/uploads/2015/01/Faculty-Handbook.pdf.

Fort Valley State University. (2020b). About Fort Valley State University. https://www.fvsu.edu/mission

Fort Valley State University. (2020c). Key Dates in FVSU History. https://www.fvsu.edu/key-dates-fvsu-history/

Gonzalez-Herrero, A., \& Pratt, C. B. (1996). An integrated model for crisis communication management. Journal of Public Relations Research, 8(2), 79-105.

Grambling State University. (2020). Grambling State University History. https://www.gram.edu/aboutus/history/

Heath, R. L. (2010). Introduction: crisis communication: defining the beast and demarginalizing key publics. The Handbook of Crisis Communication, 1-13.

Hsieh, H., \& Shannon, S. (2005). Three Approaches to Qualitative Content Analysis. Qualitative Health Research, 15(9), 1277-1288. https://doi.org/10.1177/1049732305276687

Jaques, T. (2007). Issue Management and Crisis Management: An Integrated, Nonlinear, Relational Construct. Public Relations Review, 33(2), 147-157.

Jaques, T. (2012). Crisis Leadership: a view from the executive suite. Journal of Public Affairs, 12 (4) 366-372 https://doi.org/10.1002/pa.1422

Jaques, T. (2017a). Why crisis management is a boardroom responsibility. Better Boards Conference, 28- 29.

Jaques, T. (2017b). It's time to rethink crisis management. Communication Director, 1 (1) 37-39

Johnson, M. (2019). Six tactics to renew Historically Black Colleges and Universities: Educating readers for the $21^{\text {st }}$ century. The Edwin Mellen Press.

Kezar, A. (2014). Governance and Decision-making in Colleges and Universities: Shared Governance, Governance Structure, External Influences, Trends in Governance. https://education.stateuniversity.com/pages/2014/Governance-Decisionmaking-in-Colleges-Universities.html 
Kezar, A., Carducci, R., \& Contreras-McGavin, M. (2006). Rethinking the " $L$ " word in higher Education. Wiley \& Sons.

Krippendorff, K. (2013). Content analysis: An introduction to its methodology. SAGE.

Lerbinger, O. (2012). The Crisis Manager: Facing Disasters, Conflicts, and Failures. Erlbaum

National Center for Education Statistics. (2020). College Navigator: Fort Valley State University. https://nces.ed.gov/collegenavigator/?q=fort+Valley+university\&s=all\&id $=139719 \#$ \#programs

National Center for Education Statistics. (2020). College Navigator: Grambling State University.

https://nces.ed.gov/collegenavigator/?q=grambling\&s=all\&id=159009\#pro grams

National Center for Education Statistics. (2020). College Navigator: Savannah State University.

https://nces.ed.gov/collegenavigator/?q=Savannah + State\&s $=$ all\&id $=14096$ $\underline{\text { 0\# } \text { enrolmt }}$

National Center for Education Statistics. (2020). College Navigator: Southern University. and $A \& M$ College. https://nces.ed.gov/collegenavigator/?q=southern + University + and $+\mathrm{A}+\% 26$ $+\mathrm{M} \& \mathrm{~s}=$ all\&id $=160621 \#$ enrolmt

Nelms, C. \& Schexnider, A. J. (2020a). Strengthening governance at Historically Black Colleges and Universities. Diverse Education. https://diverseeducation.com/article/172253/

Nelms, C. \& Schexnider, A. J. (2020b). Prerequisites for HBCU governance. American Governing Boards. https://agb.org/blog-post/prerequisites-forhbcu-governance/

Richards, D. A. R., \& Awokoya, J. T. (2012). Understanding HBCU retention and completion. Frederick D. Patterson Research Institute, UNCF

Savannah State University (2020). History of SSU. https://www.savannahstate.edu/about-ssu/history.shtml

Savannah State University (2020). Faculty Handbook. https://www.savannahstate.edu/faculty-senate/documents/facultyhandbook-approved-by-senate-and-president-april-2019.pdf

Simola, S. (2014). Teaching corporate crisis management through business ethics education. European Journal of Training \& Development, 38(5), 483-503.

Southern University Office of Institutional Effectiveness. (2020). Southern University and Agricultural \& Mechanical College Factbook 2019-2020. https://www.subr.edu/assets/subr/OIE/Fact-Book-2019-2020.pdf

Southern University System. (2020). SU Board Minutes Archive. https://www.sus.edu/page/board-minutes-2020-archive

Thompson, S. (2018). Ghana's Changing Tide: A Case Study of Internationalization of Education at A Ghanaian Higher Education 
Institution. [Doctoral dissertation, Southern University \& A \&M College].

ProQuest. https://search-proquest-

com.subr.idm.oclc.org/docview/2170674835/70A52091D02548F5PQ/1?ac

countid $=14135$

Thurgood Marshall College Fund. (2019a). About HBCUs.

https://www.tmcf.org/about-us/member-schools/about-hbcus/

Thurgood Marshall College Fund. (2019b). History of HBCUs.

https://www.tmcf.org/history-of-hbcus/

Topper, B., \& Lagadec, P. (2013). Fractal Crises - A New Path for Crisis Theory and Management. Journal of Contingencies and Crisis

Management, 21(1), 4-16. https://doi:10.1111/1468-5973.12008

University of Louisiana System. (2020). Board of Supervisors.

https://www.ulsystem.edu/board-members/

University System of Georgia. (2020). Board of Regents Meetings.

https://www.usg.edu/regents/meetings/date/2020

U.S. Department of Education. (2020). Title III Part B, Strengthening Historically

Black Colleges and Universities Program.

https://www2.ed.gov/programs/iduestitle3b/eligibility.html

Vlabrun, M. (2020, March 18). Black Colleges Feeling Collective Pain. Inside

Higher Ed. https://www.insidehighered.com/news/2020/03/18/blackcolleges-lobby-stimulus-funds

Wood, S. (2020, November 19). Panel explores accreditation and role of HBCUs during COVID-19 crisis. Diverse Issues in higher education https://diverseeducation.com/article/197025/

Yanovitzky, I., \& Weber, M. (2020). Analysing use of evidence in public policymaking processes: a theory-grounded content analysis methodology. Evidence \& Policy, 16(1) 65-82. https://doi.org/10.1332/174426418X15378680726175

MELANIE S. JOHNSON, PhD, is an Assistant Professor of Political Science at Southern University and A\&M College. Her major research interests focus on public policy, governance, leadership, and change in higher education, particularly at Historically Black Colleges and Universities (HBCUs).

Email: melanie_johnson@subr.edu

SAMANTHA A. THOMPSON, PhD, is an Analyst for Institutional Effectiveness at the Southern University Law Center (SULC). Her major research interests encompass the areas of international and comparative higher education, internationalization of education, Historically Black Colleges and Universities (HBCUs), and education policy research. Email: sthompson@sulc.edu

Manuscript submitted: July 23, 2020

Manuscript revised: December 11, 2020

Accepted for publication: January 11, 2021 